\title{
Human neurons express type I GnRH receptor and respond to GnRH I by increasing luteinizing hormone expression
}

\author{
Andrea C Wilson ${ }^{1,2}$, M Shahriar Salamat ${ }^{1}$, Ryan J Haasl ${ }^{2}$, Kelly M Roche ${ }^{2}$, Anjali Karande ${ }^{3}$, \\ Sivan Vadakkadath Meethal ${ }^{2}$, Ei Terasawa ${ }^{5}$, Richard L Bowen ${ }^{6}$ and Craig S Atwood ${ }^{1,2,4}$ \\ ${ }^{1}$ Department of Pathology and Laboratory Medicine, Veterans Administration Hospital, University of Wisconsin, 2500 Overlook Terrace, Madison, \\ Wisconsin 53705, USA \\ ${ }^{2}$ Department of Medicine, University of Wisconsin and Geriatric Research, Education and Clinical Center, Veterans Administration Hospital, \\ Madison, Wisconsin 53705, USA \\ ${ }^{3}$ Department of Biochemistry, Indian Institute of Science, Bangalore, India \\ ${ }^{4}$ Institute of Pathology, Case Western Reserve University, Cleveland, Ohio 44106, USA \\ ${ }^{5}$ Department of Pediatrics, University of Wisconsin, Madison, Wisconsin 53706, USA \\ ${ }^{6}$ Voyager Pharmaceutical Corporation, Raleigh, North Carolina 27615, USA \\ (Requests for offprints should be addressed to C S Atwood; Email: csa@medicine.wisc.edu) \\ ( $\mathrm{R}$ L Bowen is now at OTB Research, Raleigh, North Carolina 27615, USA)
}

\begin{abstract}
Gonadotropin-releasing hormone receptor I (GnRHR I) has been localized to the limbic system of the rat brain, although the functional consequences of $\mathrm{GnRH}$ signaling through these receptors is unknown. In this paper, we characterize the expression of GnRHR I in the human hippocampus and cortex, and the functionality of GnRHR I in human neuroblastoma cells. Robust GnRHR I immunoreactivity was detected in the cell body as well as along the apical dendrites of pyramidal neurons in the CA2, CA1, and end plate, but was clearly lower in the subiculum of the hippocampus. Immunolabeling was also evident in cortical neurons, including those located in the entorhinal cortex and occipitotemporal gyrus but was not observed within the granular layer of the dentate gyrus. No differences in immunohistochemical staining were observed between control and Alzheimer's disease brain. GnRHR I mRNA and protein (mature, immature, and other variant) expression was detected in human neuroblastoma cells (M17, SH-SY5Y) and
\end{abstract}

rat embryonic primary neurons and varied with differentiation and GnRH treatment. Since GnRHR I was expressed by extrapituitary cells, and hypothalamic GnRH I secretion markedly increases post-menopause/andropause, we treated human M17 neuroblastoma cells cultured in serum-free conditions with GnRH I for $6 \mathrm{~h}$ and measured LH expression. M17 neuroblastoma cells express LH $\beta$ mRNA, while immunoblot analysis indicated the presence of three $\mathrm{LH}$ variants (approximately 30, 47, and $60 \mathrm{kDa}$ ) that were upregulated by low concentrations of GnRH I, but downregulated at higher $\mathrm{GnRH}$ I concentrations. LH expression was also found to increase in differentiating embryonic rat primary cortical neurons. Our results demonstrate that neurons expressing GnRHR I are functional, responding to GnRH I by upregulating LH production. Post-reproductive surges in GnRH I secretion may explain the accumulation of $\mathrm{LH}$ in pyramidal neurons of the aged human and rat.

Journal of Endocrinology (2006) 191, 651-663

\section{Introduction}

Luteinizing hormone $(\mathrm{LH})$ is secreted from gonadotropes of the anterior pituitary into the bloodstream following pulsatile stimulation by hypothalamic gonadotropin-releasing hormone I (GnRH I; Larsen et al. 2002). LH has also been immunolocalized to the cytoplasm of neurons of the cerebral cortex and hippocampus of the human and rat brains (Hostetter et al. 1981, Emanuele et al. 1983, Bowen et al. 2002), and is found in the cerebrospinal fluid (Bagshawe et al. 1968).

The exact origin of extrapituitary intracellular $\mathrm{LH}$ is unclear. One possible explanation is that pyramidal neurons sequester LH from extracellular sources (e.g. blood). This is supported by the findings that pyramidal neuron LH is elevated approximately twofold in Alzheimer's disease (AD) compared with age-matched control brains (Bowen et al. 2002), an increase that correlates with a twofold increase in serum LH (Bowen et al. 2000, Hogervorst et al. 2001, Short et al. 2001). Another intriguing possibility is that aging neurons, like fetal and cancer cells, might be capable of synthesizing LH (Whitfield \& Kourides 1985, Krichevsky et al. 1995, Yokotani et al. 1997). This latter idea is supported by the findings that (1) mRNA for LH has been localized to pyramidal neurons of the cerebral cortex and hippocampus of the aging rat brain (Lee et al. 2004), (2) GnRH receptor I (GnRHR I) is localized to extrapituitary cells in the rodent 
brain including the hippocampus, amygdala, entorhinal cortex, and subiculum, with lower levels in the septum, frontal cortex and hypothalamus (Reubi \& Maurer 1984, Badr \& Pelletier 1987, Haour et al. 1987, Reubi et al. 1987, Jennes et al. 1988, 1995, 1996, 1997, Leblanc et al. 1988, Badr et al. 1989, Ban et al. 1990, Thompson \& Moss 1992, Crumeyrolle-Arias et al. 1994, Pierpaoli \& Lesnikov 1997, Lu et al. 1999, Granger et al. 2004), and (3) the pulsatile release of GnRH I from the hypothalamus is dramatically elevated following menopause (Gill et al. 2002, Gore et al. 2004). The increased binding of GnRH I to gonadotrope GnRHR I results in dramatic elevations in the synthesis and secretion of gonadotropins following menopause and andropause (Gharib et al. 1990, Couzinet \& Schaison 1993, Woller et al. 2002). The presence of GnRHR I on neurons of the brain implies that GnRH I also might signal through these neurons to increase LH synthesis and secretion.

Understanding the source of neuronal LH has implications for our understanding of neoplasia (Whitfield \& Kourides 1985, Krichevsky et al. 1995, Yokotani et al. 1997) and AD (Bowen \& Atwood 2004). With regards to AD, LH promotes the amyloidogenic processing of the amyloid- $\beta$ precursor protein to generate amyloid- $\beta$, the major component of amyloid plaques that deposit in AD (Bowen et al. 2004). In addition, the GnRH I analog, leuprolide acetate, which suppresses serum LH, has been shown to decrease amyloid load in the brains of normal and aged amyloid- $\beta$ precursor protein $(\mathrm{A} \beta \mathrm{PP})$-transgenic mice, and maintain cognitive performance in aged $\mathrm{A} \beta \mathrm{PP}$-transgenic mice (Bowen et al. 2004, Casadesus et al. 2006).

Given the above observations, we examined whether neurons express GnRHR I, and like pituitary gonadotropes, respond to $\mathrm{GnRH}$ I by expressing $\mathrm{LH}$. We report that GnRHR I is localized to the cell body and apical dendrites of pyramidal neurons in the human hippocampus, entorhinal cortex, and occipitotemporal gyrus, and that neurons are capable of de novo LH synthesis. GnRH I may therefore play a role in regulating biochemical events associated with post-reproductive neuronal senescence.

\section{Materials and Methods}

\section{Antibodies and reagents}

The high-affinity LH polyclonal antibody generated against the $\beta$-subunit of the $\mathrm{LH}$ glycoprotein was from $\mathrm{Dr} A \mathrm{~F}$ Parlow at the National Hormone and Peptide Program, Harbor-UCLA Medical Center, Torrance, CA, USA. The GnRHR I monoclonal antibody, $F_{1} G_{4}$, directed against the N-terminal amino acid residues 1-29 was from Dr Anjali Karande (Indian Institute of Science, Bangalore, India). The GnRHR I polyclonal antibody, C-18, directed against 18 C-terminal residues, and the GAPDH polyclonal antibody were from Santa Cruz Biotechnologies (Santa Cruz, CA, USA). Neuron specific enolase (NSE) was purchased from
Signet Laboratories (Dedham, MA, USA). Horseradish peroxidase linked goat anti-mouse, goat anti-rabbit, and donkey anti-goat IgG were from Santa Cruz Biotechnologies. Goat affinity purified antibody to mouse IgG was from MP Biomedicals (Aurora, OH, USA) and the mouse peroxidase anti peroxidase (PAP) was from Steinberger Monoclonals Inc. (Lutherville, MD, USA). Isotype-matched antibody IgG1 was from Santa Cruz Biotechnologies. The low range pre-stained (approximately 20-120 kDa) molecular weight markers were from Bio-Rad Laboratories.

Primary rat cortical neurons (E18) were purchased from Brain Bits (Springfield, IL, USA). Opti-Mem, Dulbecco's modified Eagle's media (DMEM), modified Eagle's media (MEM), and F12 Nutrient Mixture B27 supplement were from Invitrogen. The media supplement, insulin-transferrinselenium, was purchased from Sigma Laboratories. GnRH I peptide was from Peninsula Laboratories (San Carlos, CA, USA). Protease inhibitor cocktail (aprotinin, pepstatin, leupeptin, and phenylmethylsulphonyl fluoride) was from Roche Diagnostics. The Luteinizing Hormone Detection Kit was from Hope Laboratories (Belmont, CA, USA).

\section{Immunohistochemistry}

Human hippocampal tissue was collected at autopsy from clinically and pathologically confirmed cases of AD using National Institute for Aging (NIA) and Consortium to Establish a Registry for Alzheimer's Disease (CERAD) criteria (Khachaturian 1985, Mirra et al. 1991; Table 1). Tissues were formalin-fixed, embedded in paraffin, sectioned at $4 \mu \mathrm{m}$ thickness and placed on SP Brand Superfrost Plus slides (Cardinal Health, Dublin, OH, USA).

Tissue sections were deparaffinized with xylene and then hydrated through a series of ethanols. Endogenous peroxidase activity was eliminated with a $30-$ min incubation in $3 \% \mathrm{H}_{2} \mathrm{O}_{2}$ in methanol. Following placement of the sections in citrate buffer $(1 \mathrm{mM}, \mathrm{pH} 6 \cdot 0)$, slides were autoclaved at $121{ }^{\circ} \mathrm{C}$ for $30 \mathrm{~min}$ and then rinsed well. Non-specific binding sites were blocked with $10 \%$ normal goat serum in tris buffered saline (TBS; $20 \mathrm{mM}$ Tris, $150 \mathrm{mM} \mathrm{NaCl}, \mathrm{pH}$ 7.6) for $30 \mathrm{~min}$ before application of GnRHR I monoclonal antibody $\mathrm{F}_{1} \mathrm{G}_{4}(1: 250$ dilution) overnight at $4{ }^{\circ} \mathrm{C}$. After a series of washes, tissue sections were incubated with both the goat affinity purified antibody to mouse $\operatorname{IgG}(1: 50$ dilution, $30 \mathrm{~min})$ and the mouse PAP (1:250 dilution, $60 \mathrm{~min}$ ). Immunostaining was then developed using diaminobenzidine (DAKO Corporation, Carpinterie, CA, USA) for $10 \mathrm{~min}$, slides mounted using Permount (Fisher Chemicals, Fair Lawn, NJ, USA) and staining analyzed under an inverted microscope (Zeiss Axiophot, Thornwood, NY, USA). To control for nonspecific primary or secondary antibody binding, control tissue sections were treated with isotype-matched $\mathrm{IgG}_{1}$ primary antibody or secondary antibody respectively. Sections were scored by three investigators for hippocampal (CA2, CA1, end plate, and subiculum) labeling. An Olympus Optical BX40F 
Table 1 Immunohistochemical labeling of human hippocampal (CA2, CA1, end plate, subiculum) tissue for GnRHR I in Alzheimer's disease (AD) and age-matched control subjects

\begin{tabular}{|c|c|c|c|c|c|c|c|c|c|}
\hline & Age (years) & Gender & Diagnosis & Brain weight & Post-mortem delay & End plate & CA2 & CA1 & Subiculum \\
\hline \multicolumn{10}{|c|}{ Subject } \\
\hline 2 & 72 & M & Control & $1375 \mathrm{~g}$ & $\mathrm{~N} / \mathrm{A}$ & + & + & ++ & - \\
\hline 5 & 71 & M & Control & N/A & $21 \mathrm{~h} 20 \mathrm{~min}$ & + & + & ++ & - \\
\hline 11 & 74 & $\mathrm{~F}$ & Control & $1223 \mathrm{~g}$ & $7 \mathrm{~h} 15 \mathrm{~min}$ & ++ & ++ & ++ & + \\
\hline 14 & 68 & M & Control & $1200 \mathrm{~g}$ & $3 \mathrm{~h} 30 \mathrm{~min}$ & ++ & ++ & + & + \\
\hline 17 & 71 & $\mathrm{~F}$ & Control & $\mathrm{N} / \mathrm{A}$ & $2 \mathrm{~h} 5 \mathrm{~min}$ & ++ & +++ & ++ & + \\
\hline 24 & 65 & M & Control & $1370 \mathrm{~g}$ & $5 \mathrm{~h} 54 \mathrm{~min}$ & ++ & +++ & ++ & ++ \\
\hline 1 & 70 & M & $\mathrm{AD}$ & $1300 \mathrm{~g}$ & $21 \mathrm{~h} 50 \mathrm{~min}$ & + & + & + & + \\
\hline 3 & 90 & M & $A D$ & $1300 \mathrm{~g}$ & $\mathrm{~N} / \mathrm{A}$ & + & + & ++ & + \\
\hline 4 & 88 & $\mathrm{~F}$ & $A D$ & $1100 \mathrm{~g}$ & $3 \mathrm{~h} 45 \mathrm{~min}$ & + & ++ & + & $\mathrm{N} / \mathrm{A}$ \\
\hline 23 & 76 & $\mathrm{~F}$ & $A D$ & $1060 \mathrm{~g}$ & $7 \mathrm{~h} 25 \mathrm{~min}$ & ++ & ++ & + & + \\
\hline 25 & 86 & $\mathrm{~F}$ & $A D$ & $1040 \mathrm{~g}$ & 20 h $55 \mathrm{~min}$ & ++ & ++ & + & - \\
\hline 29 & 82 & $\mathrm{~F}$ & $A D$ & $1100 \mathrm{~g}$ & $2 \mathrm{~h} 5 \mathrm{~min}$ & + & ++ & + & - \\
\hline
\end{tabular}

Neuronal staining:,,,-++++++ , or ++++ ; where - represents no cellular staining and ++++ represents staining equivalent to the strongest signal observed in pituitary gonadotropes. N/A, not available; area of subiculum was infarcted and a score could not be determined.

microscope at objective $10 \times$ magnification was used to capture images using Image Pro software.

\section{Human brain tissue homogenization and immunoblot analysis}

Human frontal area 9 (frontal cortical) brain tissues were kindly provided by the Sanders-Brown Center on Aging at the University of Kentucky, Lexington, KY, and pituitary was provided by the University of Wisconsin/Veteran's Administration Brain Bank. Age, gender, and post-mortem interval (PMI) matched samples (approximately $150 \mathrm{mg}$ ) of seven AD cases (ages 84-93) and seven control cases (ages 83-92) were homogenized in $300 \mu \mathrm{l}$ PBS, containing $10 \mu \mathrm{g} / \mathrm{ml}$ aprotinin and leupeptin, $1 \mu \mathrm{g} / \mathrm{ml}$ pepstatin $\mathrm{A}, 1 \mathrm{mM}$ phenylmethanesulfonyl fluoride, $1 \%$ Triton-X100, $0 \cdot 2 \%$ NP40, and $0 \cdot 1 \%$ SDS) over ice. Samples were centrifuged at $9000 \mathrm{~g}$ for $10 \mathrm{~min}$ and the supernatant removed and stored at $-80{ }^{\circ} \mathrm{C}$ for future analysis.

Following protein assay (BCA assay Pierce, Rockford, IL, USA), equal amounts of protein were loaded onto 10-20\% Tricine precast gels (Novex, San Diego, CA, USA). Samples then underwent immunoblot analysis as described previously using GnRHR I monoclonal antibody, glyceraldehyde-3phosphate dehydrogenase (GAPDH) primary antibody, and GnRHR I polyclonal (C-18) antibody.

\section{M17 neuroblastoma cell culture, treatment, and immunoblotting}

Human M17 neuroblastoma cells were maintained at $37{ }^{\circ} \mathrm{C}$ in OPTI-MEM media containing $0.5 \%$ FBS and $1 \%$ penicillin/streptomycin $(\mathrm{P} / \mathrm{S} ; 100 \mathrm{U} / \mathrm{ml}$ penicillin, 100 $\mathrm{mg} / \mathrm{ml}$ streptomycin). Human SH-SY5Y neuroblastoma cells were maintained in MEM and F12 medias (1:1 ratio) containing $10 \% \mathrm{FBS}$ and $1 \% \mathrm{P} / \mathrm{S}$. For experiments, cells were plated $48 \mathrm{~h}$ prior to treatment at a density of approximately $5 \cdot 0 \times 10^{5}$ cells/well in six-well plates. The following day, cultures were placed in serum-free media (DMEM supplemented with $1 \%$ insulin/transferrin/sodium selenite supplement) for $24 \mathrm{~h}$ prior to treatment with $0-10 \mu \mathrm{M}$ GnRH I peptide. Cells were then collected using lysis buffer (Tris $20 \mathrm{mM}$, NaCl $150 \mathrm{mM}, 1 \%$ SDS, $1 \mathrm{mM}$ EDTA, $1 \mathrm{mM}$ EGTA, and protease inhibitors; $\mathrm{pH} 7 \cdot 6$ ), the protein concentration determined using the BCA Assay and equal amounts of protein loaded onto 10-20\% tricine gels (Novex). Samples were then transferred onto polyvinylidene fluoride (PVDF) membranes (Bio-Rad Laboratories), fixed with 4\% glutaraldehyde in TBS Tween-20 (TBST), blocked with 10\% milk in TBST for $2 \mathrm{~h}$ and probed with a rabbit polyclonal antibody against human LH (dilution 1:1000). Following a series of TBST washes on the second day, the blot was incubated with the appropriate secondary antibody for $2 \mathrm{~h}$ at room temperature, washed again and developed with ECL reagent (Amersham). The chemiluminescent signal was captured on autoradiographs (Eastman Kodak Company, Aurora, IL, USA). The blot was then stripped using Restore stripping buffer (Pierce) and subsequently reprobed with the GnRHR I monoclonal antibody and finally a GAPDH antibody as a loading control for quantification. Images were captured, scanned, and the intensity of the autoradiograph signals (including a blank region) was determined using the NIH Image J software (http://rsb.info.nih.gov/nih-image/). Control and treatment values were corrected for blank values, normalized to their respective GAPDH band intensity and the results then expressed as a fold change over control levels.

\section{Primary rat cortical neuron culture}

Neuronal cultures were taken from frontal cortices of Sprague-Dawley rat embryonic (E18) pups. The cells were dissociated by tituration in Hibernate E media (Brain Bits), undispersed tissue allowed to settle for $1 \mathrm{~min}$, and the supernatant transferred to a new tube prior to centrifugation for $1 \mathrm{~min}$ at $200 \mathrm{~g}$. The supernatant was then removed and the cells resuspended in serum-free Neurobasal medium (without 
phenol red) with B-27 supplement (Invitrogen), $25 \mu \mathrm{M}$ L-glutamate, $1 \% \mathrm{P} / \mathrm{S}$ and $0.5 \mathrm{mM}$ L-glutamine, counted using a hemocytometer and then equal volumes of mixed cells were plated into six-well $\left(1 \times 10^{6}\right.$ cells/well; Fisher $)$ poly-L-lysinecoated plates (Sigma). Cortical cultures were allowed to differentiate in $5 \% \mathrm{CO}_{2}, 85 \%$ humidity in the above media for up to 12 days and then collected for immunoblot analysis. Following protein assay, gels were loaded with equal amounts of protein. A loading control (such as tubulin and actin) was not assessed since the expression of these proteins increase with differentiation (Drubin et al. 1988).

\section{LH secretion assay}

Human M17 neuroblastoma cells were cultured in OPTIMEM media (Invitrogen) containing 0.5\% FBS and 1\% P/S for $72 \mathrm{~h}$ or until confluence was reached. Cells were then treated in serum-free conditions with $0-10 \mu \mathrm{M}$ GnRH I for $48 \mathrm{~h}$. Media were collected and stored at $-80{ }^{\circ} \mathrm{C}$ prior to enzyme immunoassay (Hope Laboratories) to quantitate media LH concentration. Two human serum samples containing low and high concentrations of LH were included as controls for the assay.

\section{Detection of GnRHR I and LH mRNA}

Total RNA was isolated from cultured M17 cells using the RNeasy Mini Kit (Qiagen) according to the manufacturer's instructions. GnRHR I and LH $\beta$ cDNA were synthesized and amplified using the SuperScript III One-Step RT-PCR system (Invitrogen). Both cDNA synthesis and PCR amplification were carried out using gene-specific primers: GnRHR I forward 5' AGCAGACAGCTCTGGACAGACAAA 3', reverse $5^{\prime}$ ACATAGTAGGGAGTCCAGCAGACA $3^{\prime}$. LH $\beta$ forward 5' GCTACTGCCCCACCATGATG 3', reverse $5^{\prime}$ ATGGACTCGAAGCGCACATC $3^{\prime}$. The PCR product was run on $4 \%$ Metaphor agarose gel (Cambrex Bio Science, Rockland, ME, USA) or $20 \%$ polyacrylamide gel (Invitrogen), and amplified DNA extracted using a QIA quick gel extraction kit (Qiagen). Extracted PCR product was cycle sequenced using a BigDye Terminator v3.1 Cycle Sequencing Kit (Applied Biosystems, Madison, WI, USA) and automated sequencing was performed at the University of Wisconsin Biotechnology Center (Madison, WI, USA). To confirm that the sequenced PCR products were in fact human GnRHR I or LH $\beta$ cDNA and not the result of amplification of residual genomic DNA in the RNA sample, sequenced PCR products were aligned with the known GnRHR I mRNA sequence (Accession number AY392011), or the LH $\beta$ mRNA sequence (Accession number NM_000894) and checked for the absence of an intronic sequence.

\section{Statistical analysis}

For immunohistochemical labeling of AD and control tissues, scores from three investigators for hippocampal (CA2, CA1, end plate, and subiculum) labeling of GnRHR I were averaged. Statistical analysis of the expression of GnRHR I variants between $\mathrm{AD}$ and age-matched control samples was conducted using a two-sample $t$-test (between groups) (Statview 5.0; SAS Institute, Inc Cary, NC, USA).

\section{Results}

Immunolocalization of GnRHR I to human pyramidal and cerebrocortical neurons

To determine whether GnRHR I is expressed by neurons of the human brain, hippocampal and neocortical tissue sections were immunostained using the $\mathrm{F}_{1} \mathrm{G}_{4}$ monoclonal GnRHR I antibody that detects the N-terminal 29 amino acids (Karande et al. 1995). Immunoreactivity was clearly present throughout the hippocampus and neocortex in the cell body of large pyramidal neurons and extended along the apical dendrites of these neurons (Figs 1 and 2). GnRHR I immunostaining in the hippocampus compared favorably with GnRHR I immunostaining in gonadotropes of the human pituitary (Fig. 1).

To determine if GnRHR I expression varied throughout the hippocampus, immunolabeling was scored in four main regions of the hippocampus: CA2, CA1, end plate, and subiculum (Fig. 2; Table 1). Labeling was most prominent in the CA2 sector (Fig. 2; Table 1), was noted in the end plate and CA1 sector, but was clearly less in the subiculum when compared with the other hippocampal sectors (Table 1). Labeling was also evident in neocortical neurons, including those located in the entorhinal cortex and occipitotemporal gyrus (Fig. 2). Staining was not observed within the granular layer of the dentate gyrus or in other neuronal cell types.

To determine if there were differences in the expression of GnRHR I between control tissues and tissue from the AD brain, age-matched AD brain tissues were stained for GnRHR I. Immunolabeling of AD tissues was clearly evident in the regions described above for control tissues (Fig. 2). No significant differences in labeling intensity were observed between control and AD tissues (Table 1). However, labeling was clearly decreased on apical dendrites of pyramidal neurons in the AD compared with control brains (Fig. 2; upper versus lower panels). Tissues incubated with an isotype-matched primary antibody or with the secondary antibody alone were not labeled (not shown). These results demonstrate that like the rat, GnRHR I is present on neurons of the human hippocampus and neocortex and is not solely located within the anterior pituitary.

\section{$A D$ and age-matched control human cortices express $G n R H R I$}

To examine if there were differences in GnRHR I expression between age-matched controls and AD, immunoblot analyses of total homogenate from the frontal cortex were performed using the $\mathrm{F}_{1} \mathrm{G}_{4}$ antibody (Karande et al. 1995). Three main GnRHR I variants were present, 


\section{HIPPOCAMPUS}
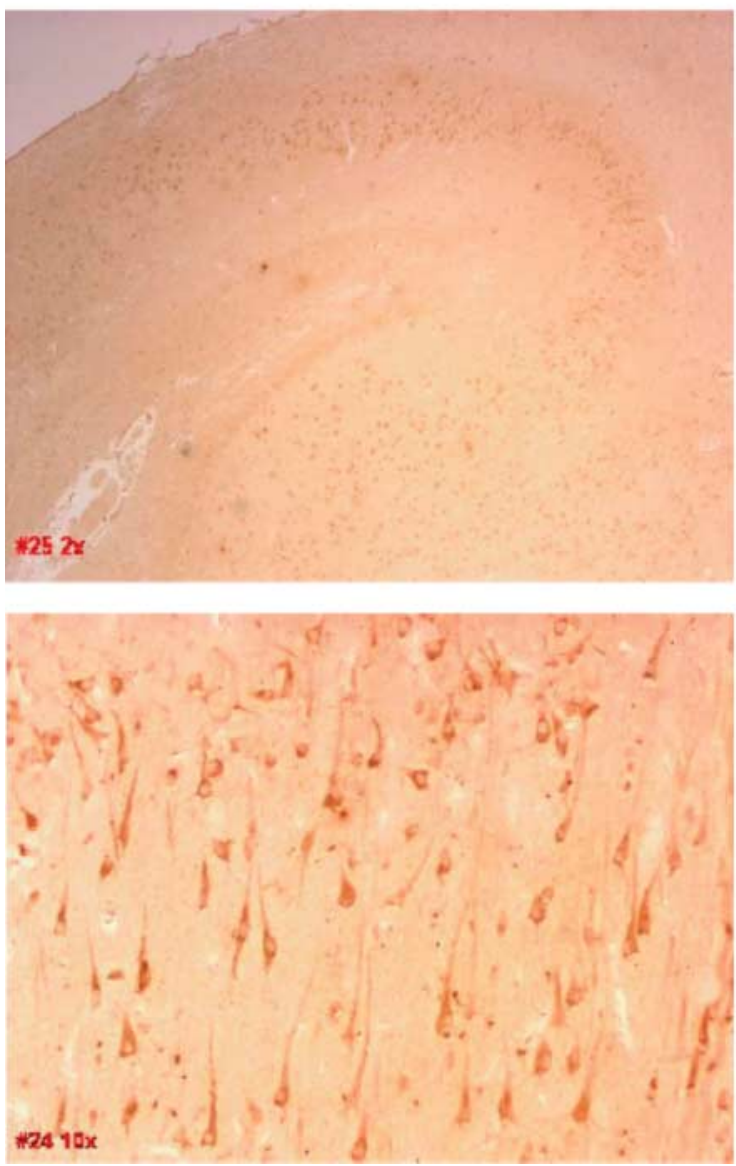

PITUITARY
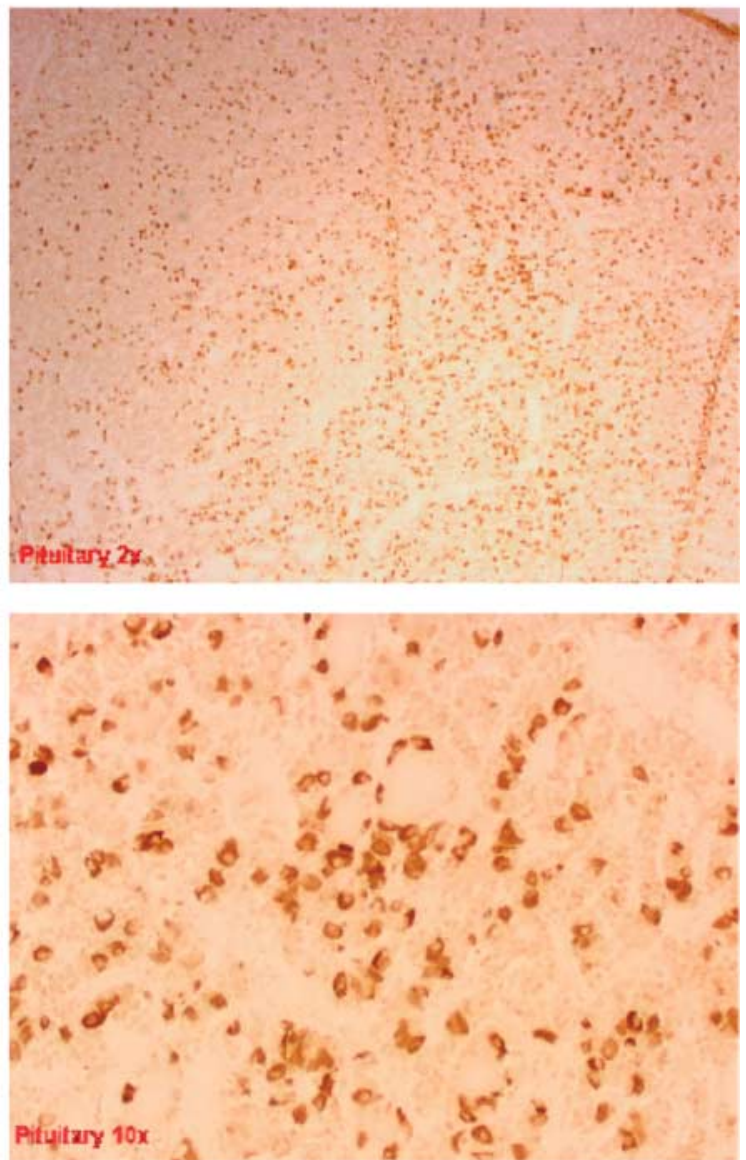

Figure 1 Immunolabeling of GnRHR I in the human hippocampus and pituitary. Human hippocampal and pituitary tissue (positive control) were immunolabeled with the GnRHR I monoclonal antibody, $F_{1} G_{4}$. Upper panels illustrate GnRHR I immunolabeling throughout the hippocampus and pituitary (objective magnification $2 \times$ ). Lower panels illustrate labeling of hippocampal pyramidal neurons and pituitary gonadotropes (objective magnification of $10 \times$ ).

including a $30 \mathrm{kDa}$ GnRHR I variant, the mature $64 \mathrm{kDa}$ variant (Wormald et al. 1985, Karande et al. 1995), a $136 \mathrm{kDa}$ variant, and two minor variants migrating at approximately 77 and $94 \mathrm{kDa}$ that might represent differentially post-translated proteins or receptor complex components (Fig. 3a; Conn \& Venter 1985, Wormald et al. 1985, Stojilkovic \& Catt 1995, Keller et al. 2005b). These same variants were also expressed in the pituitary, where the $94 \mathrm{kDa}$ variant predominated (Fig. 3c). Quantification of the major variant bands indicated a 41, 28, and $86 \%$ decrease in the relative intensities of the 30, 64, and $136 \mathrm{kDa}$ variants between control and AD brain respectively that reached significance with the 30 and $136 \mathrm{kDa}$ variants when normalized to the GAPDH loading control (Fig. 3b). To determine whether the decrease in GnRHR I expression was a result of neuron loss in the $\mathrm{AD}$ brains, we reprobed the blot with NSE. As expected, the level of NSE was lower in the AD compared with control cortex. Normalization of the GnRHR I expression against NSE indicated that only the $136 \mathrm{kDa}$ variant was significantly decreased in the AD brain (Fig. 3b).

To confirm that there were no changes in the mature $64 \mathrm{kDa}$ variant, we reprobed the blot using the C18 polyclonal GnRHR I antibody that has been shown to recognize only the mature uncomplexed form of the receptor (Bajo et al. 2003, Keller et al. 2005b). We detected one band migrating at $64 \mathrm{kDa}$, the mature form of the receptor (Wormald et al. 1985, Karande et al. 1995, Keller et al. 2005a; Fig. 4a). This band also was detected in homogenized pituitary tissue (Fig. 4b; Hazum et al. 1987). As noted above for the monoclonal antibody, GnRHR I (64 kDa) expression was not different between control and AD tissues (quantitation not shown). These results indicate that mature GnRHR I variant expression is similar in both $A D$ and control cortical tissue, but that there is a differential expression of the $136 \mathrm{kDa}$ variant between AD and age-matched control cortex. Together, these results demonstrate the localization of GnRHR I on both human hippocampal and cortical tissues. 


\section{HIPPOCAMPUS}
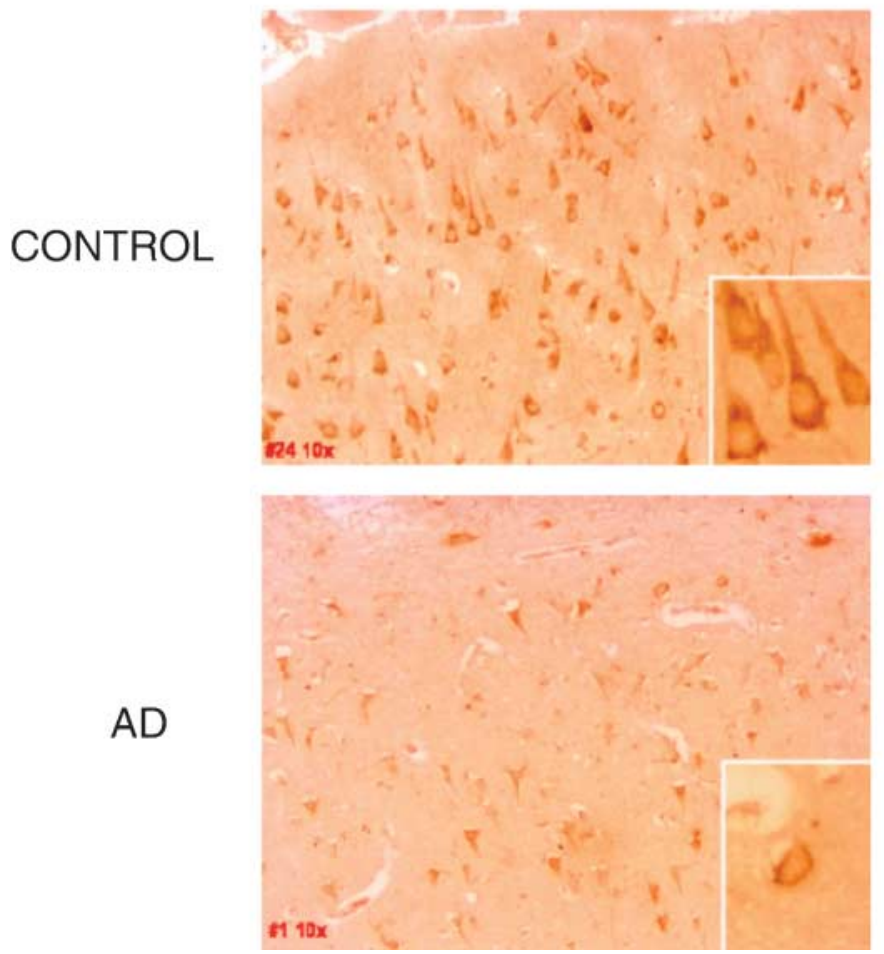

NEOCORTEX
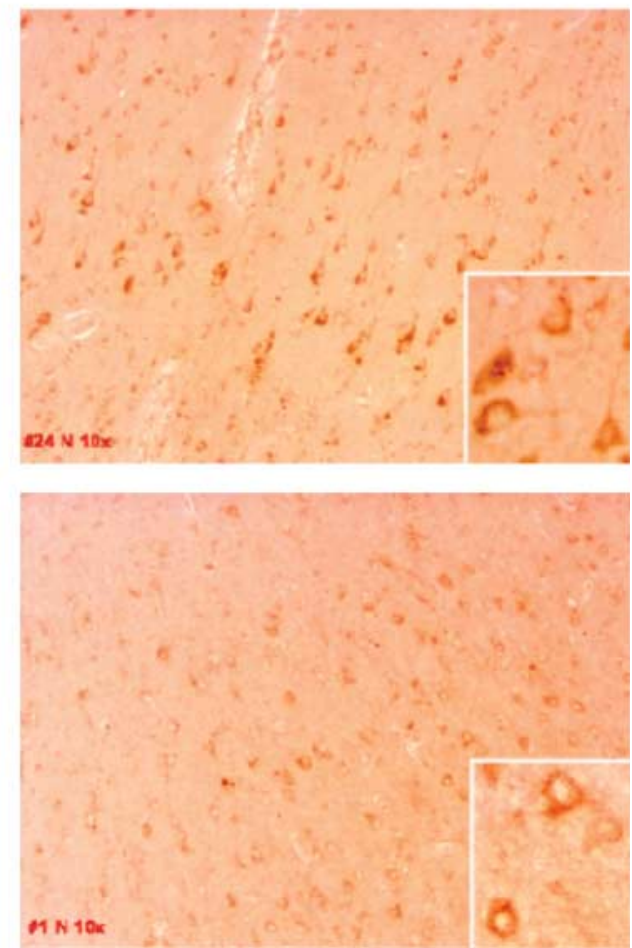

Figure 2 Immunolocalization of GnRHR I in human control and AD hippocampal and cortical neurons. Immunolabeling of control hippocampus (upper left) and neocortex (upper right) with the GnRHR I monoclonal antibody $\mathrm{F}_{1} \mathrm{G}_{4}$ demonstrates GnRHR I localization to the cell body and apical dendrites (case \#24). Immunolabeling of AD hippocampus (lower left) and neocortex (lower right) demonstrates GnRHR I localization predominantly to the cell body (case \#1). Insets are representative neurons from the $10 \times$ pictures, taken at $40 \times$ objective magnification to illustrate membrane labeling.

GnRH I induces the expression of LH in neuroblastoma cells and primary cortical neurons

Given that GnRHR I mediates signaling for the synthesis and secretion of LH by pituitary gonadotropes, we examined the functionality of neuronally expressed GnRHR I in terms of LH expression in human M17 and SH-SY5Y neuroblastoma cells cultured in serum-free media. Immunoblot analysis under reducing conditions and using the well-characterized polyclonal antibody anti-human-LHß (Parlow 2004) indicated that neuroblastoma cells express three LH variants, including the mature $30 / 31 \mathrm{kDa}$ full-length protein (Nureddin \& Johnson 1977) and two minor variants migrating at approximately 43 and $47 \mathrm{kDa}$ that might represent differentially post-translated proteins (Fig. 5a, lane 1 and d). A $60 \mathrm{kDa}$ band also was detected that might represent a dimer. Since the anti-human LH $\beta$ antibody was generated against the entire $\beta$-subunit of the LH glycoprotein, the increase in expression of the mature $30 \mathrm{kDa}$ protein suggests that $\mathrm{GnRH}$ promotes the expression of both LH $\beta$ and glycoprotein hormone alpha subunit ( $\boldsymbol{\alpha}-\mathrm{GSU})$. To confirm LH expression, isolated RNA was reverse transcribed and LH $\beta$ cDNA amplified using two gene-specific primers. The expected $95 \mathrm{bp}$ cDNA fragment encompassing portions of exons 2 and 3 was detected
(Fig. 5c). The sequence of the amplified cDNA matched the genomic sequence (minus the intronic sequences) demonstrating that the amplified cDNA was from LH $\beta$ mRNA template.

We next tested whether neuroblastoma cells respond to GnRH I by increasing LH expression. Treatment of M17 cells with increasing concentrations of human GnRH I $(0-10 \mu \mathrm{M})$ for $6 \mathrm{~h}$ initially increased the expression of all LH variants. Quantitation of the immunoblots indicated that the expression of the 30 and $47 \mathrm{kDa}$ variants were approximately two- to threefold elevated between 1 and $10 \mathrm{nM}$, but at high GnRH I concentrations ( $\geq 1000 \mathrm{nM}$ ), the expression of both LH variants was suppressed (Fig. 5b). To examine whether primary neurons also express $\mathrm{LH}$, cortical neurons from day 18 rat embryos were differentiated over 12 days. An increase in the expression of the $30 \mathrm{kDa}$ full-length $\mathrm{LH}$ was apparent with differentiation (Fig. 5e). These results indicate that $\mathrm{LH}$ mRNA and protein are normally expressed by neurons.

To determine whether changes in LH expression following GnRH I treatment was a result of GnRHR I activation, we examined GnRHR I expression in the neuroblastoma samples, using the monoclonal antibody $F_{1} G_{4}$ described above. Immunoblot analysis indicated that M17 neuroblastoma cells 

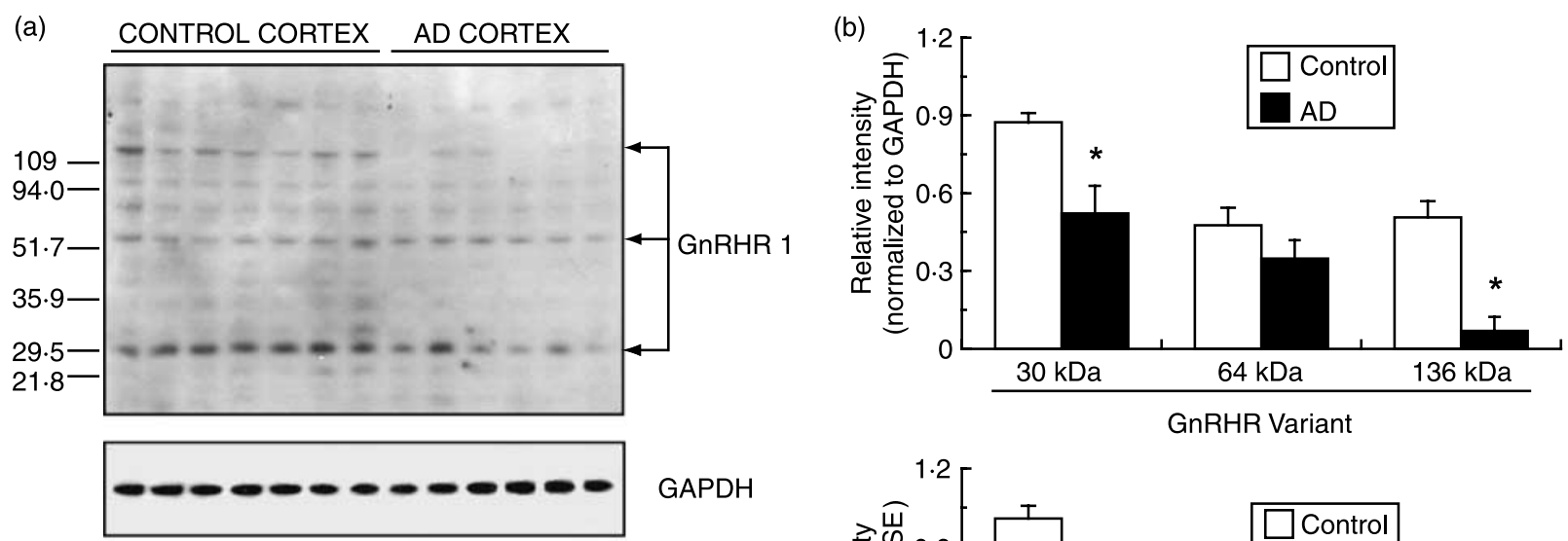

GAPDH

NSE

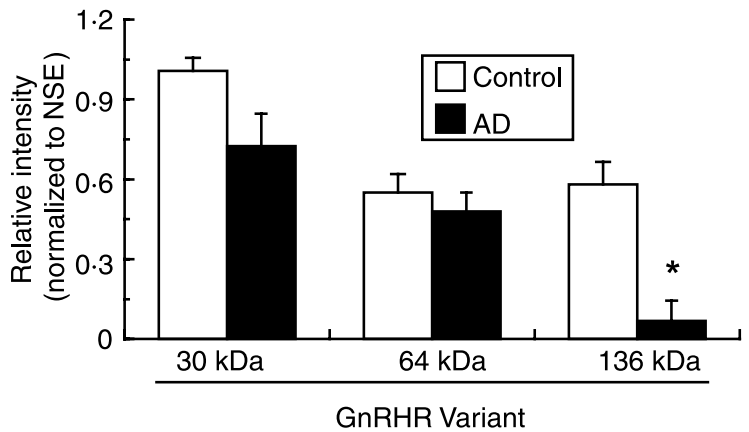

(c)

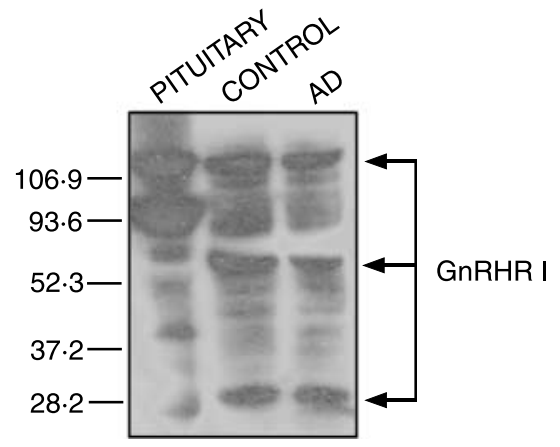

GnRHR Variant

Figure 3 GnRHR I expression in the cortex of age-matched control and AD subjects. (a) GnRHR I expression was examined in homogenized age-matched $\mathrm{AD}$ and control cortical tissue by immunoblot analysis using the GnRHR I monoclonal antibody, $\mathrm{F}_{1} \mathrm{G}_{4}$. The blot was reprobed for tissue (GAPDH) and neuron-specific (NSE) loading controls. (b) Quantification of the three prominent GnRHR I variants revealed significant decreases in the 30 and $136 \mathrm{kDa}$ in AD compared with age-matched control tissue when normalized to the GAPDH loading control (mean \pm s.D., $n=6-7, * P<0 \cdot 01$ ). A significant decrease was maintained only for the approximately $136 \mathrm{kDa}$ receptor complex in AD tissue after normalization against the NSE loading control (mean \pm s.D., $n=6-7, * P<0 \cdot 01$ ). (c) Immunoblot analysis of pituitary and representative control and AD cortex revealed similar GnRHR I variants. Molecular weight markers are illustrated on the left of figures.

(a)

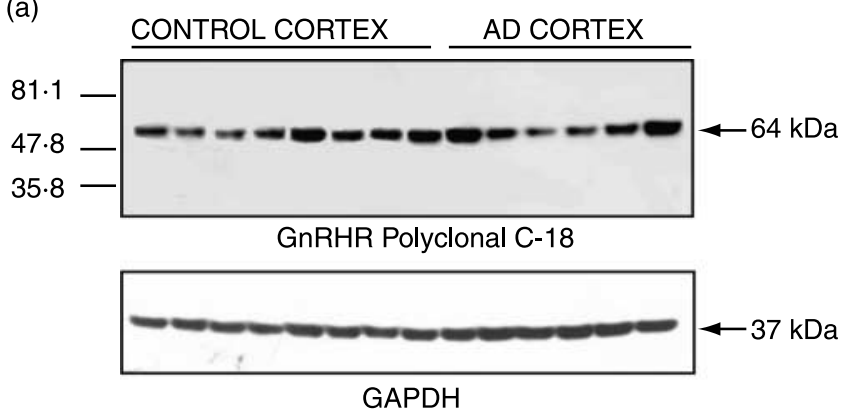

(b)

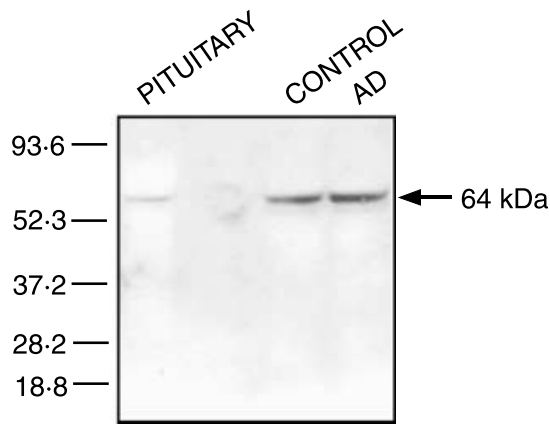

Figure 4 GnRHR I expression in the cortex of age-matched control and AD subjects. (a) The immunoblot in (Fig. 3a) was reprobed with a polyclonal antibody against the C-terminus of GnRHR I (C-18). One distinct band at approximately $64 \mathrm{kDa}$, representative of the functional GnRHR I variant, was detected. (b) The samples in (Fig. 3c) were immunoprobed with the polyclonal antibody against the C-terminus of GnRHR I (C-18). A single approximately $64 \mathrm{kDa}$ band is present in both pituitary and brain. Molecular weight markers are illustrated on the left of figures. 

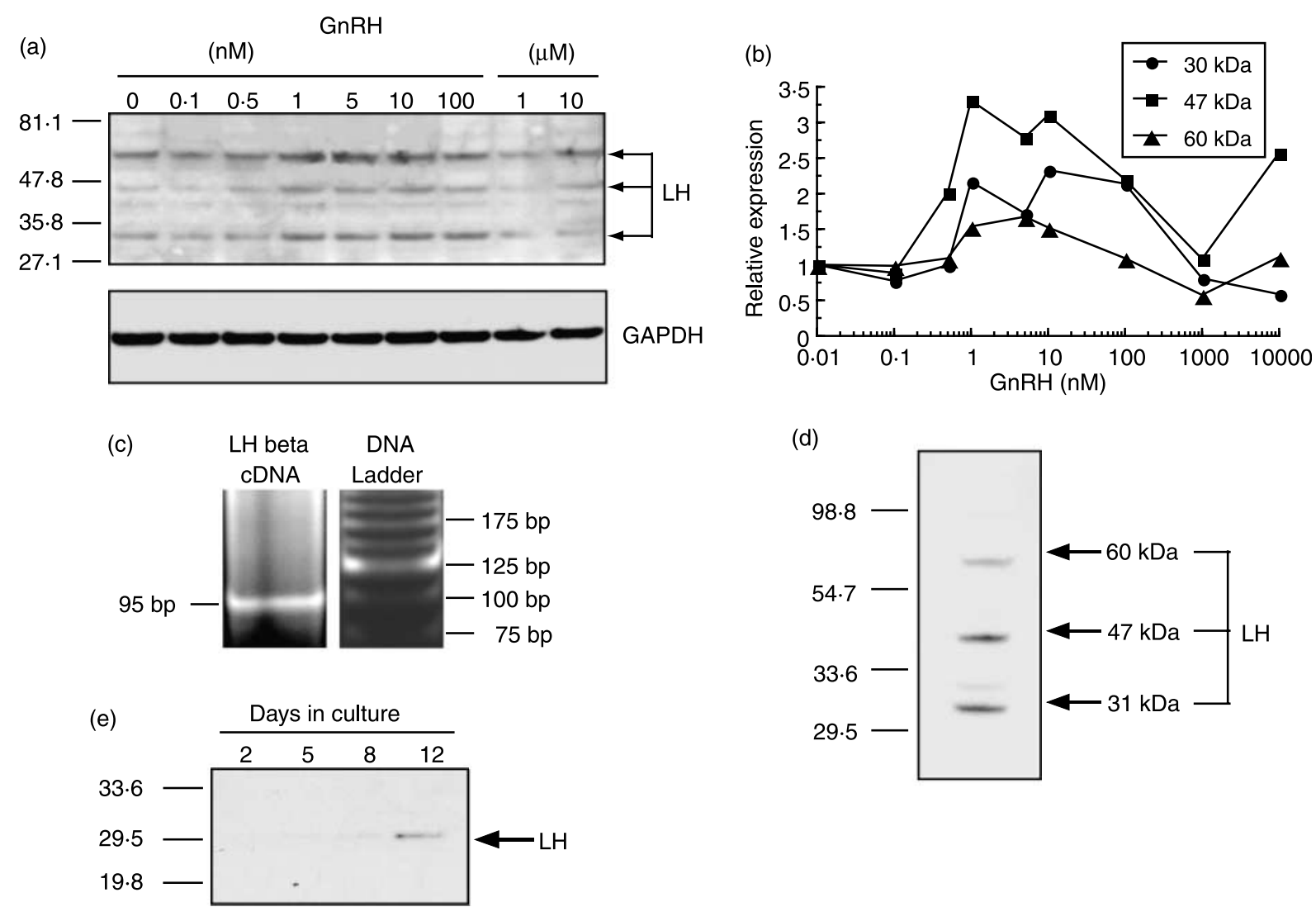

Figure 5 LH expression on neuronal cell types and its modulation by GnRH. (a) Human M17 neuroblastoma cells cultured in defined, serumfree media were treated with increasing concentrations of $\mathrm{GnRH} I(0-10 \mu \mathrm{M})$ for $6 \mathrm{~h}$ and then collected for immunoblot analysis of LH expression using the polyclonal anti-human $\beta$-LH antibody. (b) Relative intensities of the 30, 47, and $60 \mathrm{kDa}$ bands were normalized to the loading control, GAPDH. Data are representative of three experiments. (c) LH $\beta$ cDNA was detected in human M17 neuroblastoma cells. (d) Human SH-SY5Y neuroblastoma cells express similar LH variants as described above for M17 cells. (e) Primary cortical neurons from embryonic day 18 rats cultured in serum-free conditions demonstrate increased LH (30 kDa) expression with differentiation. Molecular weight markers are illustrated on the left of figures.

express a number of GnRHR I variants, including the immature $37 \cdot 7 \mathrm{kDa}$ full-length protein (deduced from the amino acid sequence), a $30 \mathrm{kDa}$ variant which may represent a truncated variant, and a $136 \mathrm{kDa}$ variant that represents the functional form of the receptor (Conn \& Venter 1985; Fig. 6a). Similar variants were observed in SH-SY5Y neuroblastoma cells (data not shown). To confirm GnRHR I expression, isolated RNA was reverse transcribed and GnRHR I cDNA amplified using two gene-specific primers. The expected $308 \mathrm{bp}$ cDNA fragment encompassing parts of exons 2 and 3 was detected (Fig. 6c). The sequence of the amplified cDNA matched the genomic sequence (minus the intronic sequences) demonstrating that the amplified cDNA was from the GnRHR I mRNA template. These results indicate that GnRHR I mRNA and protein is normally expressed by neurons. Expression of the $37 \cdot 7 \mathrm{kDa}$ immature form of the receptor did not alter with increasing concentrations of GnRH I. However, the levels of the 30 and $136 \mathrm{kDa}$ variants initially decreased with increasing $\mathrm{GnRH} I$ concentration before increasing at higher GnRH concentrations (Fig. 6b). Immunoblot analysis of these samples using the GnRHR I polyclonal antibody against a C-terminal stretch of 18 amino acids revealed only one band that was representative of the immature $37.7 \mathrm{kDa}$ variant (data not shown). Overall, these results indicate that transcription of the immature form of the receptor is not affected by GnRH I, but that receptor complex formation and/or post-translational modification of the GnRHR I is modulated by GnRH I.

Immunoblot analysis of differentiating rat cortical primary neurons for GnRHR I indicated that the same variants were expressed (approximately 30, 37, and $136 \mathrm{kDa}$; Fig. 6d) as for the human neuroblastoma cell lines (Fig. 6a). GnRHR I expression increased with neuron differentiation (i.e. neuritic outgrowth), and since equal amounts of protein were loaded at each time point, these results suggest that neurites may express proportionally more GnRHR I than the neuronal cell body.

Together, these results indicate that neurons, (1) express mature and post-translationally modified variants of $\mathrm{LH},(2)$ respond to GnRH I by increasing the expression of $\mathrm{LH}$, and 


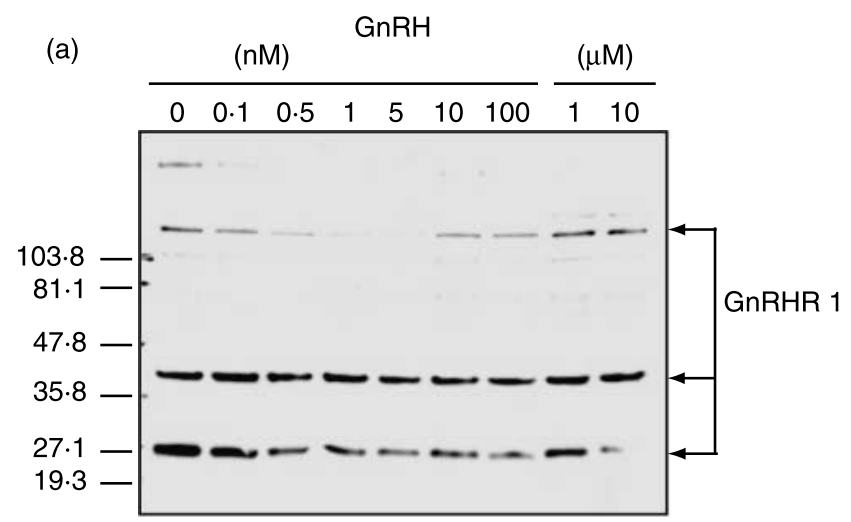

(b)
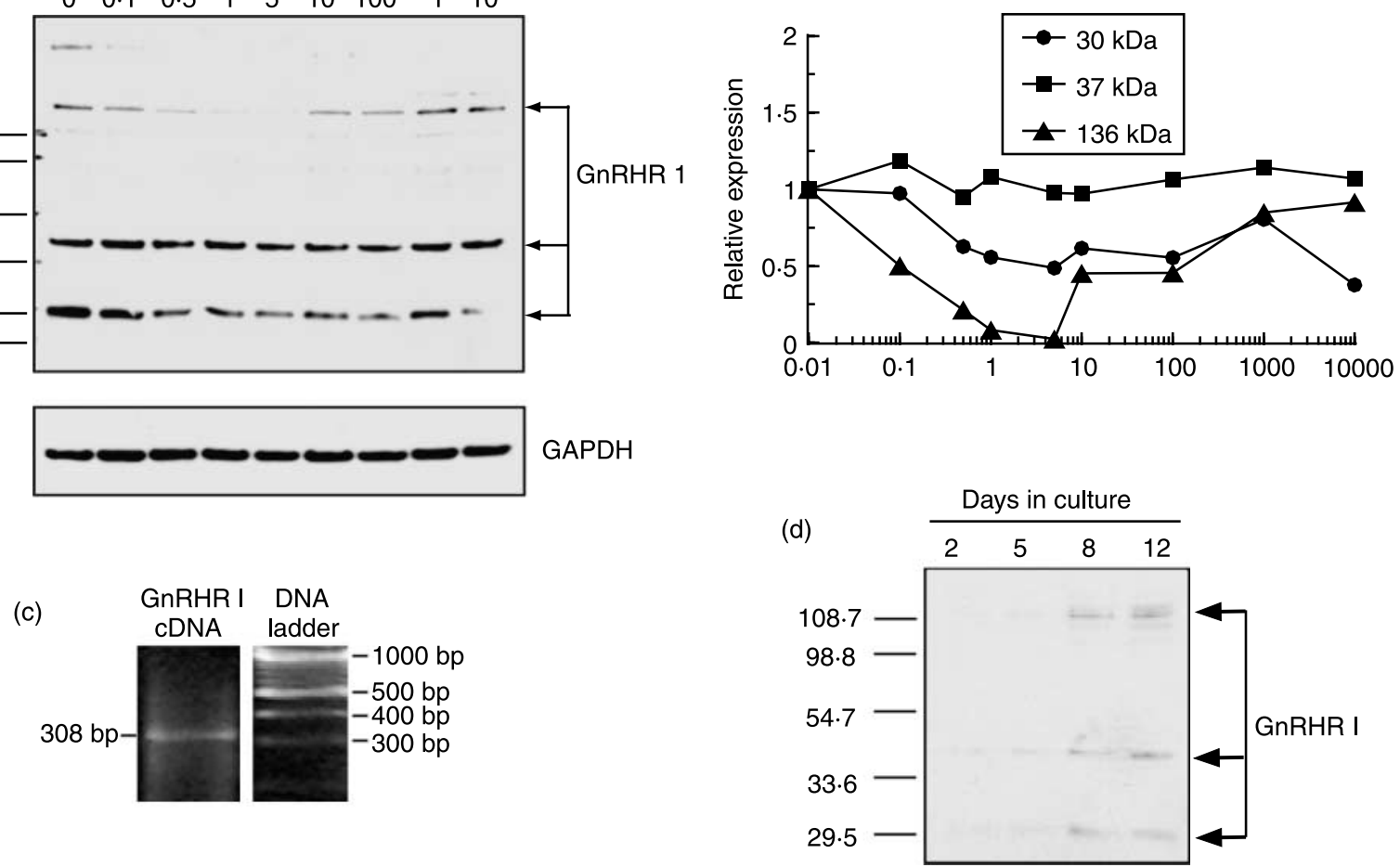

Figure 6 GnRHR I expression on neuronal cell types and its modulation by GnRH. (a) The immunoblot from Fig. 4a was stripped and reprobed with the $\mathrm{F}_{1} \mathrm{G}_{4}$ monoclonal GnRH I receptor antibody. Three major GnRHR I variants were detected: approximately, 30, 37, and $136 \mathrm{kDa}$. (b) Relative intensities of GnRH I receptor variants were normalized to GAPDH. Decreases in the levels of the approximately 30 and $136 \mathrm{kDa}$ GnRHR I variants were observed with increasing GnRH I concentrations. The data are representative of three experiments. (c) GnRHR I cDNA was detected in human M17 neuroblastoma cells. (d) The immunoblot from Fig. 5e was stripped and reprobed with the $\mathrm{F}_{1} \mathrm{G}_{4}$ monoclonal $\mathrm{GnRH}$ I receptor antibody. The expression of approximately 30, 37, and $136 \mathrm{kDa}$ GnRHR I variants increased with neuron differentiation. Equal protein was loaded at each time point. Molecular weight markers are illustrated on the left of figures.

(3) possess functional GnRHR I as illustrated by the modulation of LH and GnRHR I expression by GnRH I.

\section{Discussion}

Expression of GnRHR I by neuronal cells

Although GnRHR I has been localized to extrapituitary regions of the rodent brain, we demonstrate for the first time the presence of GnRHR I on pyramidal neurons of the hippocampus and neocortical neurons of the entorhinal cortex and occipitotemporal gyrus of the human brain (Figs 1-4). The presence of GnRHR I throughout the neuron body as well as in the apical dendrites of pyramidal neurons, but not in neurons of the granular cell layer, suggests that GnRH I signaling plays an important role in the function of hippocampal neurons. In this respect, previous studies have shown that leuprolide acetate, a potent GnRHR I agonist, induces a long-lasting enhancement of synaptic transmission mediated by ionotropic glutamate receptors in CA1 pyramidal neurons of rat hippocampal slices (Lu et al. 1999). The use of GnRH analogs in modulating synaptic transmission and neuronal metabolism in these areas of the brain requires further investigation due to its implications in learning and memory.

Immunoblot analysis of human cortical tissue confirmed the presence of three major GnRHR I variants: the mature $64 \mathrm{kDa}$ receptor, a $30 \mathrm{kDa}$ truncated variant and an approximately $136 \mathrm{kDa}$ complex variant (Fig. 3). Although there were considerable individual variations in the expression of GnRHR I variants, the expression of the mature $64 \mathrm{kDa}$ variant (Wormald et al. 1985, Karande et al. 1995, Keller et al. 2005a) was not different between control and AD brains (Fig. 3). Interestingly, radiation inactivation analysis of GnRHR I (a method for determining the functional molecular weight of a receptor while it is still a component of the plasma membrane) indicates that GnRHR I has a molecular mass of $136346 \pm 8120$ (Conn \& Venter 1985). This estimate is approximately twice of that obtained by immunoblot analyses (Karande et al. 1995, Keller et al. 2005a; Fig. 3) and by photoaffinity labeling with a radioactive GnRH analog followed by electrophoresis under denaturing conditions (Wormald et al. 1985). The high molecular weight band present under our non-reducing conditions in both the 
brain and neuroblastoma cells may therefore represent a high molecular weight complex of GnRHR I in its native state, coupled to G-proteins and other associated proteins, as has been reported for numerous other G-protein coupled receptors (reviewed by Park et al. 2004). The low expression level of the mature $64 \mathrm{kDa}$ variant in neuroblastoma cells, and of the immature $37 \cdot 7 \mathrm{kDa}$ variant in the brain, suggests rapid posttranslational modification and complexing of GnRHR I to other components of the receptor complex.

GnRHR I expression on transformed cell lines (Fig. 6) has previously been reported for the human olfactory FNC-B4 cell line (Romanelli et al. 2004), as well as numerous other cancer cell lines originating from the prostate, kidney, skin, lymphocytes, liver, larynx, pancreas, colon, and brain (Fekete et al. 1989, Friess et al. 1991, Pati \& Habibi 1995, van Groeninghen et al. 1998, Krebs et al. 2002, Moretti et al. 2002, Ben-Yehudah \& Lorberboum-Galski 2004). Rat primary cortical neurons express the same GnRHR I variants as neuroblastoma cells (Fig. 5) indicating that neoplastic transformation does not affect GnRHR I expression. The functionality of these receptors is indicated by the GnRH I-induced decrease in the expression of the $136 \mathrm{kDa}$ receptor complex in neuroblastoma cells (Fig. 6b). A similar decrease in the expression of the $136 \mathrm{kDa}$ receptor complex $(-86 \%)$ was noted in the AD brain (Fig. 3b), a time when LH/ follicle stimulating hormone (FSH) and presumably GnRH I levels are high (Bowen et al. 2000). Since continuous GnRH I stimulation of the GnRHR I is known to 'desensitize' receptor signaling, our results suggest that GnRH I may promote the uncoupling of GnRHR I from G-proteins and other proteins of the receptor complex (Fig. 6; Park et al. 2004). Alternatively, GnRH I may promote the internalization and degradation of the receptor complex (Adams et al. 1986).

\section{Expression of LH by neurons}

We report that primary neurons and neuroblastoma cells express the gonadotropin $\mathrm{LH}$, and that $\mathrm{LH}$ expression is modulated in a dose-dependent manner by GnRH I (Fig. 5). The expression of LH in neurons grown in serum-free media (Fig. 5) indicates that neuronal LH was not sequestered from the serum but synthesized de novo. LH expression increased with differentiation in primary cortical neurons, suggesting that LH expression is a normal function of differentiated neurons. In neuroblastoma cells, GnRH I promoted a similar pattern of expression for all the three major LH variants $(30,47$, and $60 \mathrm{kDa}$ ); LH expression increased with increasing GnRH I concentrations, but at high GnRH I concentrations the expression of $\mathrm{LH}$ decreased. The increase in the expression of $\mathrm{LH}$ variants was first detectable at $0.5 \mathrm{nM}$ GnRH I (Fig. 5), which is within the affinity range of GnRH I and GnRH I analogs for GnRHR I $\left(K_{\mathrm{d}}=0 \cdot 1-1 \mathrm{nM}\right)$ in the hippocampus of the rat (reviewed by Vadakkadath Meethal \& Atwood 2005). GnRH I did not alter the expression of the $37 \cdot 7 \mathrm{kDa}$ variant of GnRHR I over this short treatment period $(6 \mathrm{~h})$ at any concentration (Fig. 6) indicating that a mechanism independent of the regulation of GnRHR I expression mediated the decrease in LH expression (it is unlikely that GnRH I was acting through the 30 and $136 \mathrm{kDa}$ variants, since their expression decreased with increasing GnRH I concentration when $\mathrm{LH}$ expression was increasing). The decline in cellular LH at high GnRH I concentrations over this short time $(6 \mathrm{~h})$ is unlikely to be explained by GnRH I-induced secretion of LH, since we did not detect LH secretion into media (data not shown), although it cannot be ruled out that neuroblastoma cells secrete low levels of LH. It is therefore likely that desensitization of GnRH I signaling was induced by continuous GnRH I treatment that has previously been shown with other $G$ protein-coupled receptors to involve rapid uncoupling of the receptor from the G-protein and loss of downstream signaling events (and which is followed by subsequent sequestration of the receptor from the plasma membrane, internalization, and proteolytic degradation; Cheng \& Leung 2000).

At least 39 isoforms of human LH have been identified (Nureddin \& Johnson 1977, Stanton et al. 1993). The LH variants detected in human neuroblastoma cells (30, 47, and $60 \mathrm{kDa}$ ) under non-reducing immunoblot analysis have been detected in post-menopausal $(30,35$, and $43 \mathrm{kDa}$; Iles \& Chard 1991, Kurowska \& Szewczuk 1999) and pre-ovulatory urine $(29,49,67,80$, and $95 \mathrm{kDa}$; Kurowska \& Szewczuk 1999), and in the human pituitary $(29,49,60,67$, and 95 kDa; Stanton et al. 1993, Kurowska \& Szewczuk 1999).

The expression of LH by neurons is corroborated by the presence of translatable levels of LH mRNA and LH protein in pyramidal neurons of the cerebral cortex and hippocampus of the rat and human (Lee et al. 2004). Levels of neuronal LH were undetectable in adult (3-5-month old) animals but increased with age at 1 and 2 years of age. Previous studies have demonstrated the presence of membrane-associated $\mathrm{LH}$ and human chorionic gonadotropin (hCG, which has $83 \%$ amino acid sequence homology and shares a common receptor to $\mathrm{LH}$, which they bind with similar affinity) on a number of different human cancer cell lines including retinoblastoma cells cultured in serum-free conditions (Rosen et al. 1980, Acevedo et al. 1992, Krichevsky et al. 1995), (Whitfield \& Kourides 1985, Krichevsky et al. 1995, Yokotani et al. 1997).

Functional consequences of $\mathrm{GnRH}$ I induction of LH expression by neurons

The presence of GnRHR I on reproductive and nonreproductive tissues suggests $\mathrm{GnRH}$ I has physiological affects on tissues of the body other than the pituitary, including the hippocampus (Kakar \& Jennes 1995, Cheng \& Leung 2000, Harrison et al. 2004). The high binding affinity of GnRH I for its neuronal receptor and the activation by GnRH I of neuronal signal transduction pathways in the rat brain (Jennes et al. 1995, 1997) supports the functionality of extrapituitary GnRHR I. It is not clear whether GnRH I produced by the hypothalamus or by other tissues binds to and signals through these receptors throughout the body. At least for the brain, GnRHR I signaling is likely mediated through GnRH I produced by GnRH I neurons that extend throughout different regions of 
the brain (Tobet et al. 1996, Quanbeck et al. 1997, Kim et al. 1999, Reed et al. 2002). The short serum half-life of GnRH I (approximately 2-3 min; Redding et al. 1973, Fauconnier et al. 1978) would support autocrine release of GnRH I within the brain, although it has been shown in rats that GnRH I can cross the blood brain barrier (BBB) (Dvorska et al. 1992).

The increased secretion of GnRH I by GnRH I neurons following menopause (Hall et al. 2000, Gore et al. 2004) may explain the increased expression of LH in aging pyramidal neurons of the cerebral cortex and hippocampus of the rat (Lee et al. 2004). In addition, the elevation in gonadotropins (Bowen et al. 2000, Hogervorst et al. 2001, Short et al. 2001) and presumably GnRH I secretion would explain the accumulation of $\mathrm{LH}$ detected in pyramidal neurons of the AD compared with age-matched control brain (Bowen et al. 2002). LH released by pituitary gonadotropes could also transfer through perivascular pathways into the brain. The identification of $\mathrm{LH} / \mathrm{hCG}$ receptors on both endothelial and smooth muscle cells suggests a route by which LH might cross from the vasculature into the brain (Toth et al. 2001). The contribution of de novo synthesized and extracellular $\mathrm{LH}$ to total intracellular LH remains to be determined.

The functional consequences of intracellular neuronal LH production are unclear. If neuronal LH was secreted or bound to its receptor intracellularly during its processing through the estrogen receptor (ER) and/or transport to the cell membrane, then a number of scenarios are possible. First, the expression of membrane-associated glycoproteins LH/hCG is a phenotypic characteristic of human cancer cells; hCG is a common serum marker used to determine the progression of cancer and its regression following chemotherapy (Stenman et al. 2004). Thus, the elevation in LH expression in pyramidal neurons in the AD brain (Bowen et al. 2002) is suggestive of a cellular transformation from a differentiated to a mitotic phenotype. In this respect, it is becoming increasingly apparent that pyramidal neurons of the AD brain, those most vulnerable to AD neuropathology, are also those which display numerous markers of cell cycle re-entry (Raina et al. 2000, Herrup et al. 2004). Since both GnRH I and LH/hCG have mitogenic properties, it is plausible that these mitogens may drive differentiated neurons back into the cell cycle. Secondly, in this connection we have shown that LH promotes the amyloidogenic processing of A $\beta$ PP (Bowen et al. 2004), a cell cycle-related protein that releases $A \beta$ when neurons are driven into the cell cycle (McPhie et al. 2003). Likewise, LH dosedependently increases tau phosphorylation and the activity of

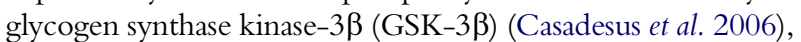
a key regulator of tau phosphorylation and neurofibrillary tangle formation. In this context, leuprolide acetate (a GnRH I analog), which suppresses serum LH levels, decreases amyloid plaque load in normal and aged A $\beta$ PP-transgenic mice and maintains the cognitive performance of $\mathrm{A} \beta \mathrm{PP}$-transgenic mice (Bowen et al. 2004, Casadesus et al. 2006). It is unclear at this stage whether leuprolide acetate is acting through the suppression of LH to alter amyloid production and cognition (Bowen et al. 2004, Casadesus et al. 2006), or directly through
GnRHRs (Figs 1-4 and 6) to modulate synaptic transmission (Lu et al. 1999). Irrespective, these data support the use of leuprolide acetate in the treatment of AD; leuprolide acetate has been shown in clinical trials to stabilize cognition in women with mild-to-moderate AD over a 1 year period (LaPlante et al. 2006). Thirdly, neuronal LH might impact neurosteroid production, since we have recently demonstrated that $\mathrm{LH}$ promotes neurosteroid production in human neuroblastoma cells and in differentiated rat primary neurons (Liu et al. 2006). Future studies will therefore be important in determining the exact role of neuronal LH.

In summary, this paper has demonstrated the presence of GnRHR I on hippocampal and cortical neurons of the human brain, differentiated rat embryonic primary neurons and human neuroblastoma cells. Our findings implicate GnRH I in the normal functioning of the brain, although the physiological significance of our unexpected finding that GnRH can induce neuronal LH synthesis remains to be fully investigated. Therefore GnRH I surges associated with the dysregulation of the hypothalamic-pituitary-gonadal (HPG) axis with menopause and andropause may mediate neurodegenerative events either directly or indirectly via LH production.

\section{Acknowledgements}

We would like to acknowledge Kela Galletti, from the Department of Surgical Pathology, for her helpful assistance in the processing and sectioning of brain tissue used for the immunohistochemistry. This work is supported by funds from the National Institute of Health (RO1 AG19356), the University of Wisconsin and the Alzheimer's Association. The authors declare that there is no conflict of interest that would prejudice the impartiality of this scientific work.

\section{References}

Acevedo HF, Krichevsky A, Campbell-Acevedo EA, Galyon JC, Buffo MJ \& Hartsock RJ 1992 Expression of membrane-associated human chorionic gonadotropin, its subunits, and fragments by cultured human cancer cells. Cancer 69 1829-1842.

Adams TE, Cumming S \& Adams BM 1986 Gonadotropin-releasing hormone $(\mathrm{GnRH})$ receptor dynamics and gonadotrope responsiveness during and after continuous GnRH stimulation. Biology of Reproduction 35 881-889.

Badr M \& Pelletier G 1987 Characterization and autoradiographic localization of LHRH receptors in the rat brain. Synapse $1567-571$.

Badr M, Marchetti B \& Pelletier G 1989 Changes in hippocampal LH-RH receptor density during maturation and aging in the rat. Brain Research. Developmental Brain Research 45 179-184.

Bagshawe KD, Orr AH \& Rushworth AG 1968 Relationship between concentrations of human chorionic gonadotrophin in plasma and cerebrospinal fluid. Nature 217 950-951.

Bajo AM, Schally AV, Halmos G \& Nagy A 2003 Targeted doxorubicincontaining luteinizing hormone-releasing hormone analogue AN-152 inhibits the growth of doxorubicin-resistant MX-1 human breast cancers. Clinical Cancer Research 9 3742-3748. 
Ban E, Crumeyrolle-Arias M, Latouche J, Leblanc P, Heurtier JF, Drieu K, Fillion G \& Haour F 1990 GnRH receptors in rat brain, pituitary and testis; modulation following surgical and gonadotropin-releasing hormone agonist-induced castration. Molecular and Cellular Endocrinology 70 99-107.

Ben-Yehudah A \& Lorberboum-Galski H 2004 Targeted cancer therapy with gonadotropin-releasing hormone chimeric proteins. Expert Review of Anticancer Therapy 4 151-161.

Bowen RL \& Atwood CS 2004 Living and dying for sex. A theory of aging based on the modulation of cell cycle signaling by reproductive hormones. Gerontology 50 265-290.

Bowen RL, Isley JP \& Atkinson RL 2000 An association of elevated serum gonadotropin concentrations and Alzheimer disease? Journal of Neuroendocrinology 12 351-354.

Bowen RL, Smith MA, Harris PL, Kubat Z, Martins RN, Castellani RJ, Perry G \& Atwood CS 2002 Elevated luteinizing hormone expression colocalizes with neurons vulnerable to Alzheimer's disease pathology. Journal of Neuroscience Research 70 514-518.

Bowen RL, Verdile G, Liu T, Parlow AF, Perry G, Smith MA, Martins RN \& Atwood CS 2004 Luteinizing hormone, a reproductive regulator that modulates the processing of amyloid-beta precursor protein and amyloidbeta deposition. Journal of Biological Chemistry 279 20539-20545.

Casadesus G, Webber KM, Atwood CS, Pappolla MA, Perry G, Bowen RL \& Smith MA 2006 Luteinizing hormone modulates cognition and amyloidbeta deposition in Alzheimer APP transgenic mice. Biochimica et Biophysica Acta 1762 447-452.

Cheng KW \& Leung PC 2000 The expression, regulation and signal transduction pathways of the mammalian gonadotropin-releasing hormone receptor. Canadian Journal of Physiology and Pharmacology 78 1029-1052.

Conn PM \& Venter JC 1985 Radiation inactivation (target size analysis) of the gonadotropin-releasing hormone receptor: evidence for a high molecular weight complex. Endocrinology 116 1324-1326.

Couzinet B \& Schaison G 1993 The control of gonadotrophin secretion by ovarian steroids. Human Reproduction 8 97-101.

Crumeyrolle-Arias M, Latouche J, Laniece P, Charon Y, Tricoire H, Valentin L, Roux P, Mirambeau G, Leblanc P, Fillion G et al. 1994 'In situ' characterization of GnRH receptors: use of two radioimagers and comparison with quantitative autoradiography. Journal of Receptor Research 14 251-265.

Drubin D, Kobayashi S, Kellogg D \& Kirschner M 1988 Regulation of microtubule protein levels during cellular morphogenesis in nerve growth factor-treated PC12 cells. Journal of Cell Biology 106 1583-1591.

Dvorska I, Brust P, Hrbas P, Ruhle HJ, Barth T \& Ermisch A 1992 On the blood-brain barrier to peptides: effects of immobilization stress on regional blood supply and accumulation of labelled peptides in the rat brain. Endocrine Regulations 26 77-82.

Emanuele N, Anderson J, Andersen E, Connick E, Baker G, Kirsteins L \& Lawrence A 1983 Extrahypothalamic brain luteinizing hormone: characterization by radioimmunoassay, chromatography, radioligand assay and bioassay. Neuroendocrinology 36 254-260.

Fauconnier JP, Teuwissen B \& Thomas K 1978 Rate of disappearance in plasma of synthetic LH-RH intravenously injected in man. Gynecologic and Obstetric Investigation 9 229-237.

Fekete M, Zalatnai A, Comaru-Schally AM \& Schally AV 1989 Membrane receptors for peptides in experimental and human pancreatic cancers. Pancreas 4 521-528.

Friess H, Buchler M, Kiesel L, Kruger M \& Beger HG 1991 LH-RH receptors in the human pancreas. Basis for antihormonal treatment in ductal carcinoma of the pancreas. International Journal of Pancreatology $\mathbf{1 0}$ $151-159$.

Gharib SD, Wierman ME, Shupnik MA \& Chin WW 1990 Molecular biology of the pituitary gonadotropins. Endocrine Reviews 11 177-199.

Gill S, Sharpless JL, Rado K \& Hall JE 2002 Evidence that GnRH decreases with gonadal steroid feedback but increases with age in postmenopausal women. Journal of Clinical Endocrinology and Metabolism 87 2290-2296.

Gore AC, Windsor-Engnell BM \& Terasawa E 2004 Menopausal increases in pulsatile gonadotropin-releasing hormone release in a nonhuman primate (Macaca mulatta). Endocrinology 145 4653-4659.

Granger A, Ngo-Muller V, Bleux C, Guigon C, Pincas H, Magre S, Daegelen D, Tixier-Vidal A, Counis R \& Laverriere JN 2004 The promoter of the rat gonadotropin-releasing hormone receptor gene directs the expression of the human placental alkaline phosphatase reporter gene in gonadotrope cells in the anterior pituitary gland as well as in multiple extrapituitary tissues.

Endocrinology 145 983-993.

Hall JE, Lavoie HB, Marsh EE \& Martin KA 2000 Decrease in gonadotropin-releasing hormone $(\mathrm{GnRH})$ pulse frequency with aging in postmenopausal women. Journal of Clinical Endocrinology and Metabolism 85 $1794-1800$.

Haour F, Dussaillant M, Leblanc P \& Rostene W 1987 [Demonstration and topographical distribution of LHRH receptors in the central nervous system in the normal and castrated male rat]. Comptes Rendus de l'Academie des Sciences. Serie III, Sciences de la vie 305 41-44.

Harrison GS, Wierman ME, Nett TM \& Glode LM 2004 Gonadotropinreleasing hormone and its receptor in normal and malignant cells. EndocrineRelated Cancer 11 725-748.

Hazum E, Schvartz I \& Popliker M 1987 Production and characterization of antibodies to gonadotropin-releasing hormone receptor. Journal of Biological Chemistry 262 531-534.

Herrup K, Neve R, Ackerman SL \& Copani A 2004 Divide and die: cell cycle events as triggers of nerve cell death. Journal of Neuroscience 24 9232-9239.

Hogervorst E, Williams J, Budge M, Barnetson L, Combrinck M \& Smith AD 2001 Serum total testosterone is lower in men with Alzheimer's disease. Neuroendocrinology Letters 22 163-168.

Hostetter G, Gallo R \& Brownfield M 1981 Presence of immunoreactive luteinizing hormone in the rat forebrain. Neuroendocrinology 33 241-245.

Iles RK \& Chard T 1991 Human chorionic gonadotropin expression by bladder cancers: biology and clinical potential. Journal of Urology 145 453-458.

Jennes L, Dalati B \& Conn PM 1988 Distribution of gonadrotropin releasing hormone agonist binding sites in the rat central nervous system. Brain Research 452 156-164.

Jennes L, Brame B, Centers A, Janovick JA \& Conn PM 1995 Regulation of hippocampal gonadotropin releasing hormone $(\mathrm{GnRH})$ receptor mRNA and $\mathrm{GnRH}$-stimulated inositol phosphate production by gonadal steroid hormones. Brain Research. Molecular Brain Research 33 104-110.

Jennes L, McShane T, Brame B \& Centers A 1996 Dynamic changes in gonadotropin releasing hormone receptor mRNA content in the mediobasal hypothalamus during the rat estrous cycle. Journal of Neuroendocrinology 8 275-281.

Jennes L, Eyigor O, Janovick JA \& Conn PM 1997 Brain gonadotropin releasing hormone receptors: localization and regulation. Recent Progress in Hormone Research 52 475-490 (discussion 490-471).

Kakar SS \& Jennes L 1995 Expression of gonadotropin-releasing hormone and gonadotropin-releasing hormone receptor mRNAs in various nonreproductive human tissues. Cancer Letters 98 57-62.

Karande AA, Rajeshwari K, Schol DJ \& Hilgers JH 1995 Establishment of immunological probes to study human gonadotropin-releasing hormone receptors. Molecular and Cellular Endocrinology 114 51-56.

Keller G, Schally AV, Gaiser T, Nagy A, Baker B, Halmos G \& Engel JB 2005a Receptors for luteinizing hormone releasing hormone expressed on human renal cell carcinomas can be used for targeted chemotherapy with cytotoxic luteinizing hormone releasing hormone analogues. Clinical Cancer Research 11 5549-5557.

Keller G, Schally AV, Gaiser T, Nagy A, Baker B, Westphal G, Halmos G \& Engel JB $2005 b$ Human malignant melanomas express receptors for luteinizing hormone releasing hormone allowing targeted therapy with cytotoxic luteinizing hormone releasing hormone analogue. Cancer Research $655857-5863$

Khachaturian ZS 1985 Diagnosis of Alzheimer's disease. Archives of Neurology 42 1097-1105.

Kim KH, Patel L, Tobet SA, King JC, Rubin BS \& Stopa EG 1999 Gonadotropin-releasing hormone immunoreactivity in the adult and fetal human olfactory system. Brain Research 826 220-229.

Krebs LJ, Wang X, Nagy A, Schally AV, Prasad PN \& Liebow C 2002 A conjugate of doxorubicin and an analog of luteinizing hormone-releasing hormone shows increased efficacy against oral and laryngeal cancers. Oral Oncology 38 657-663. 
Krichevsky A, Campbell-Acevedo EA, Tong JY \& Acevedo HF 1995 Immunological detection of membrane-associated human luteinizing hormone correlates with gene expression in cultured human cancer and fetal cells. Endocrinology 136 1034-1039.

Kurowska E \& Szewczuk A 1999 Isolation of human lutropin from woman urine and comparison of its properties with pituitary hormone. Archivum Immunologiae et Therapiae Experimentalis (Warsz) 47 179-183.

LaPlante B, Powers C, Gault J, Reynolds B \& Gregory C 2006 Stabilization of cognitive decline in Alzheimer's disease following treatment with leuprolide acetate. In 10th International Conference on Alzheimer's Disease and Related Disorders Program No. P4 353.

Larsen HP, Thorup J, Skovgaard LT, Cortes D \& Byskov AG 2002 Long-term cultures of testicular biopsies from boys with cryptorchidism: effect of FSH and LH on the number of germ cells. Human Reproduction 17 383-389.

Leblanc P, Crumeyrolle M, Latouche J, Jordan D, Fillion G, L'Heritier A, Kordon C, Dussaillant M, Rostene W \& Haour F 1988 Characterization and distribution of receptors for gonadotropin-releasing hormone in the rat hippocampus. Neuroendocrinology 48 482-488.

Lee YW, Song J, Park D, Kang HL, Kang J \& Lee SE 2004 Expression of luteinizing hormone in the rat brain. Society for Neuroscience Program 756.716.

Liu T, Wimalasena J, Bowen R \& Atwood C 2006 Luteinizing hormone receptor mediates neuronal pregnenolone production via upregulation of steroidogenic acute regulatory protein expression. Journal of Neurochemistry In Press.

Lu F, Yang JM, Wu JN, Chen YC, Kao YH, Tung CS \& Yang SN 1999 Activation of gonadotropin-releasing hormone receptors produces neuronal excitation in the rat hippocampus. Chinese Journal of Physiology 42 67-71.

McPhie DL, Coopersmith R, Hines-Peralta A, Chen Y, Ivins KJ, Manly SP, Kozlowski MR, Neve KA \& Neve RL 2003 DNA synthesis and neuronal apoptosis caused by familial Alzheimer disease mutants of the amyloid precursor protein are mediated by the $\mathrm{p} 21$ activated kinase PAK3. Journal of Neuroscience 23 6914-6927.

Mirra SS, Heyman A, McKeel D, Sumi SM, Crain BJ, Brownlee LM, Vogel FS, Hughes JP, van Belle G \& Berg L 1991 The consortium to establish a registry for Alzheimer's disease (CERAD). Part II. Standardization of the neuropathologic assessment of Alzheimer's disease. Neurology 41 479-486.

Moretti RM, Montagnani Marelli M, Van Groeninghen JC \& Limonta P 2002 Locally expressed LHRH receptors mediate the oncostatic and antimetastatic activity of LHRH agonists on melanoma cells. Journal of Clinical Endocrinology and Metabolism 87 3791-3797.

Nureddin A \& Johnson P 1977 Ultracentrifugal studies of human luteinizing hormone and its subunits: dependence on protein concentration and ionic strength. Biochemistry 16 1730-1737.

Park PS, Filipek S, Wells JW \& Palczewski K 2004 Oligomerization of G proteincoupled receptors: past, present, and future. Biochemistry 43 15643-15656.

Parlow AF 2004 National Hormone and Peptide Program (NHPP): new recombinant hormones, hypothalamic peptides, natural hormones, new antisera, and expanded hormone assay services available. Journal of Clinical Endocrinology and Metabolism 89 3618-3620.

Pati D \& Habibi HR 1995 Inhibition of human hepatocarcinoma cell proliferation by mammalian and fish gonadotropin-releasing hormones. Endocrinology 136 75-84.

Pierpaoli W \& Lesnikov V 1997 Theoretical considerations on the nature of the pineal 'ageing clock'. Gerontology 43 20-25.

Quanbeck C, Sherwood NM, Millar RP \& Terasawa E 1997 Two populations of luteinizing hormone-releasing hormone neurons in the forebrain of the rhesus macaque during embryonic development. Journal of Comparative Neurology 380 293-309.

Raina AK, Zhu X, Rottkamp CA, Monteiro M, Takeda A \& Smith MA 2000 Cyclin' toward dementia: cell cycle abnormalities and abortive oncogenesis in Alzheimer disease. Journal of Neuroscience Research 61 128-133.

Redding TW, Kastin AJ, Gonzales-Barcena D, Coy DH, Coy EJ, Schalch DS \& Schally AV 1973 The half-life, metabolism and excretion of tritiated luteinizing hormone-releasing hormone (LH-RH) in man. Journal of Clinical Endocrinology and Metabolism 37 626-631.

Reed KL, MacIntyre JK, Tobet SA, Trudeau VL, MacEachern L, Rubin BS \& Sower SA 2002 The spatial relationship of gamma-aminobutyric acid
(GABA) neurons and gonadotropin-releasing hormone ( $\mathrm{GnRH})$ neurons in larval and adult sea lamprey, Petromyzon marinus. Brain, Behavior and Evolution 60 1-12.

Reubi JC \& Maurer R 1984 Visualization of LHRH receptors in the rat brain. European Journal of Pharmacology 106 453-454.

Reubi JC, Palacios JM \& Maurer R 1987 Specific luteinizing-hormonereleasing hormone receptor binding sites in hippocampus and pituitary: an autoradiographical study. Neuroscience 21 847-856.

Romanelli RG, Barni T, Maggi M, Luconi M, Failli P, Pezzatini A, Pelo E, Torricelli F, Crescioli C, Ferruzzi P et al. 2004 Expression and function of gonadotropin-releasing hormone $(\mathrm{GnRH})$ receptor in human olfactory GnRH-secreting neurons: an autocrine GnRH loop underlies neuronal migration. Journal of Biological Chemistry 279 117-126.

Rosen SW, Weintraub BD \& Aaronson SA 1980 Nonrandom ectopic protein production by malignant cells: direct evidence in vitro. Journal of Clinical Endocrinology and Metabolism 50 834-841.

Short RA, Bowen RL, O'Brien PC \& Graff-Radford NR 2001 Elevated gonadotropin levels in patients with Alzheimer disease. Mayo Clinic Proceedings 76 906-909.

Stanton PG, Pozvek G, Burgon PG, Robertson DM \& Hearn MT 1993 Isolation and characterization of human LH isoforms. Journal of Endocrinology 138 529-543.

Stenman UH, Alfthan H \& Hotakainen K 2004 Human chorionic gonadotropin in cancer. Clinical Biochemistry 37 549-561.

Stojilkovic SS \& Catt KJ 1995 Expression and signal transduction pathways of gonadotropin-releasing hormone receptors. Recent Progress in Hormone Research 50 161-205.

Thompson TL \& Moss RL 1992 Specific binding of 125I-LHRH agonist to hippocampal membranes: fluctuations during the estrous cycle. Peptides $\mathbf{1 3}$ 891-896.

Tobet SA, Hanna IK \& Schwarting GA 1996 Migration of neurons containing gonadotropin releasing hormone $(\mathrm{GnRH})$ in slices from embryonic nasal compartment and forebrain. Brain Research. Developmental Brain Research $\mathbf{9 7}$ 287-292.

Toth P, Lukacs H, Gimes G, Sebestyen A, Pasztor N, Paulin F \& Rao CV 2001 Clinical importance of vascular $\mathrm{LH} / \mathrm{hCG}$ receptors - a review. Reproductive Biology 1 5-11.

Vadakkadath Meethal S \& Atwood CS 2005 The role of hypothalamicpituitary-gonadal hormones in the normal structure and functioning of the brain. Cellular and Molecular Life Sciences 62 257-270.

van Groeninghen JC, Kiesel L, Winkler D \& Zwirner M 1998 Effects of luteinising-hormone-releasing hormone on nervous-system tumours. Lancet 352 372-373.

Whitfield GK \& Kourides IA 1985 Expression of chorionic gonadotropin alpha- and beta-genes in normal and neoplastic human tissues: relationship to deoxyribonucleic acid structure. Endocrinology 117 231-236.

Woller MJ, Everson-Binotto G, Nichols E, Acheson A, Keen KL, Bowers CY \& Terasawa E 2002 Aging-related changes in release of growth hormone and luteinizing hormone in female rhesus monkeys. Journal of Clinical Endocrinology and Metabolism 87 5160-5167.

Wormald PJ, Eidne KA \& Millar RP 1985 Gonadotropin-releasing hormone receptors in human pituitary: ligand structural requirements, molecular size, and cationic effects. Journal of Clinical Endocrinology and Metabolism 61 1190-1194.

Yokotani T, Koizumi T, Taniguchi R, Nakagawa T, Isobe T, Yoshimura M, Tsubota N, Hasegawa K, Ohsawa N, Baba S et al. 1997 Expression of alpha and beta genes of human chorionic gonadotropin in lung cancer. International Journal of Cancer 71 539-544.

Received in final form 30 August 2006

Accepted 30 August 2006

Made available online as an Accepted Preprint 2 October 2006 